SCIENCE AND SURGERY.

\author{
The Inaugural Address at the Meeting of the Association of Surgeons \\ of Great Britain and Infland, May 13, 1920. \\ By tilf Presideiv's, Sin JOHN BLAND-SUTtoN.
}

SURGERY is probably an ancient occupation like that of the gardener, cobbler, or potter. The gardener required few tools-a knife, axe, spade, and basket : also bast and fibre. The potter required fewer, and the astonishing results he produced with his fingers on a lump of soft clay, with the aid of a wheel, made a deep impression on the minds of thoughtful men. The potter's productions resembled creative acts, and this idea is emblazoned in the Jewish and Christian conceptions of the creation of man-God made man in His own image. Gods fashioned by the potter, Dii fictiles, were regarded with reverence by the Romans.

When the potter acquired the art of firing and glazing his clay productions, he made them imperishable.

Surgeons work on very perishable material and for their own time, for manual dexterity appeals only to witnesses.

Surgery is allied to cobblery. The tools of the surgeon and the cobbler are of three kinds : cutlery-knives and shears ; implements for aiding manipulation-pincers and a last : and means for joining parts -threads, bristles, awls, or needles. Replace the last by a saw, and the tool-bag for each is complete. Denoted by their modern namesscalpel, scissors, saw, forceps, needles, sutures and ligatures-such a set of tools is sufficient for seventy-five per cent of the operations performed by surgeons.

Good craftsmen produce excellent results with simple tools. Modern surgical instruments are excellent in shape and quality, but at the time of the destruction of Pompeii, 79 в.c., tools used by surgeons were as gross as those of farriers and tinkers. The Pompeian mural painting preserved at Naples shows Iapyx attempting to remove the head of the dart from the thigh of Eneas. 'The wounded hero, supported by his faithful friends, Mnestheus and Achates, leans on his long spear; Ascanius, his son, weeps as the surgeon, with coarse forceps, tugs vainly at the dart. Venus, with her face muffled in a thin cloud, pitying but triumphant, supplies the tincture that releases the missile, heals the wound, and enables Fneas to fight again (Fig. 1).

Surgery should interest all. Everybody who survives birth is subject to a simple operation, omphalotomy, tying the navel cord. This simple act requires a piece of string and something with which to divide the cord. In the absence of knife, shears, a potsherd, or a piece of sharp flint, it may be bitten through, as in the case of animals. Surgery had its beginnings in such simple operations as omphalotomy, circumcision, and the sewing-up of wounds, and it remained a simple craft for centuries. The prime duty of the surgeon was the treatment of wounds and injuries : this involved the use of threads and needles, and implements for the reduction of dislocations.

\title{
OMPHALITIS.
}

Prehistoric midwives probably used the same kind of ligature-material that surgeons use to-day : fibre from plants, especially flax; tendon, catgut-in use for musical instruments-could scarcely escape employment as string; and silk. Though midwives tied the cord with string, surgeons did not appreciate its value for tying a cut artery until the sixteenth century, and it was in the latter part of the nineteenth that they learued the 


\section{SCIENCE AND SURGERY}

dangers attending the use of dirty threads for such purposes. In my early days surgeons waxed the threads, like cobblers, with the hope of avoiding sepsis. The use of thread for tying the umbilical cord has had a dreadful post-operative mortality from general sepsis, the umbilical vein serving as the channel of infection. The literature relating to

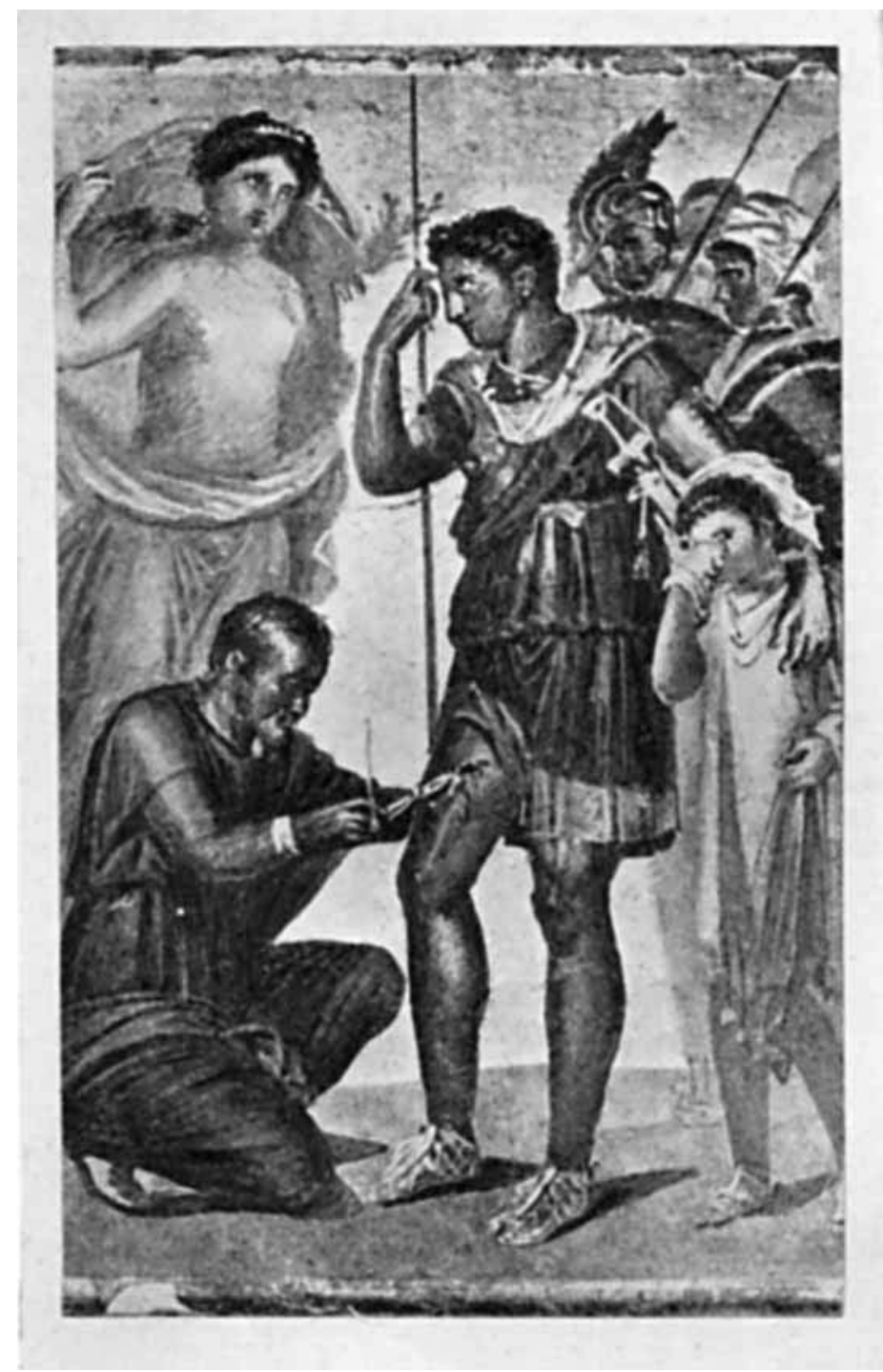

Fic. 1. - Eneas wounded. The surreon Iapyx extructing the hesl of the dart from the wound in the thigh

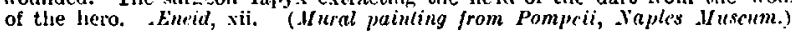

omphalitis is extensive; Miller's account of the appalling infant-mortality from this cause in the Moscow Foundling Hospitals, published in 1888, and the well-known "scourge of St. Kilda", are examples of the deadly nature of this kind of wound infection.

Omphalitis has attracted much attention during the last thirty years, and now 
strict surgical measures prevail in the birth-room, a new literature has sprung up relating to it, and as many methods are advocated for amputating the placenta as for removing a pile.

Findeavours to ascertain the cause of sepsis exercised the minds of the greatest surgeons. Seventy years ago the riddle seemed as insoluble as the cause of cancer appears to-day. Although the preparation of alcoholic beverages and bread by fermentation has been practised from remote periods, and festering wounds were as familiar as fermentation, and the rotting of dead plants and animals even more familiar, it was left to Pasteur and Lister to prove that these apparently dissimilar processes-fermentation, suppuration, and decay-are due to minutc living organisms.

\section{Particulate causes of disease.}

The microscope enabled men to discover particulate causes of disease and to discern the manner in which they are distributed in the body. When we watch with a microscope the circulation of the blood in the web of a frog's foot, the passage of the red corpuscles through the capillaries is as exciting as our first glimpse with a telescope of Jupiter's moons or the belt of Saturn. Who, fifty ycars ago, on seeing the corpuscles whirling in the blood-stream, could imagine that in a few decades improvement in technique would enable pathologists to write of the flora and fauna of the blood with the same familiarity as that with which botanists and zoologists discuss the plants and animals special to a continent?

The distribution of minute parasites in the blood is instructive; some sport in the liquor sanguinis, some select the white corpuscles, and some the red. Grosser parasites use the blood-stream for transport to favourite sites for multiplication, and some permeate the walls of the arteries. Extreme minuteness to the microscopist is like enormous distances for the astronomer. One talks confidently in micro-millimetres, and the other in millions of miles. Who shall contradict them with equal confidence ?

The Royal College of Physicians celebrates yearly the discovery of the circulation of the blood. The discovery of the lymphatic system was almost as important. Asellius found the lacteals by accident in 1622 . He opened a living dog to investigate the action of the diaphragm, saw the lacteals filled with chyle, and recognized their nature. His enthusiasm would have led him to open living men as he had dogs, but he checked this inclination (Cruikshank). Now surgeons daily open living men and interfere with the stomach; in the course of such operations they can often show to the students lacteals turgid and white with chyle (especially if the patient has swallowed some milk two hours before operation : it is a common demonstration), and thus repeat the original observation of Asellins.

Cruikshank states that Harvey never believed in the existence of lacteals. We owe much to the zealous anatomists of the Windmill Street school, who investigated the lymphatics; now their origin, course, and termination in man's body are as plainly depicted in text-books as roads are delineated on motor-maps.

Lymphatics are the subtile channels by zhich infective material reaches the circulation for distribution-and mischief.

\section{THE GLANDULAR PANTHEON.}

One of the oldest occupations is that of shepherd, and the stockyard might not inaptly be called the cradle of physiology. For centuries shepherds have known that complete removal of the genital glands renders animals useless for reproduction, but makes them docile and fat.

Few suspected that other glandular organs were associated with growth and reproduction until it was discovered that complete removal of the thyroid gland induced myxœdema. Gradually the long-suspected relationship of the thyroid to cretinism was established. As with all knowledge that depends on observation, progress was slow: 


\section{SCIENCE AND SURGERY}

"Precept must be upon precept, precept upon precept ; line upon line, line upon line ; here a little, and there a little". This surely applies to the slow accumulation of our knowledge concerning the potency of thyroid secretion. Its influence on growth has recently been studied experimentally on the metamorphosis of batrachians. Frogtadpoles change into frogs precociously if fed on mammalian thyroid. A more striking effect occurs in the axolotl (Fig. 2), the tadpole stage of the tiger salamander, but it differs from the frog-tadpole by reproducing its kind whilst in the larval stage. When the axolotl was first brought to Europe, Cuvier shrewdly suspected it to be a larva. Many years later a captive axolotl lost its gills and frills, acquired movable eyelids. quitter the water, and became a terrestrial salamander (Fig. 3). Axolotls in this country occasionally transform, and J. E. lfuxlcy las induced precocious transformation by feeding them on ox-thyroid. In his experiments the metamorphosis took place

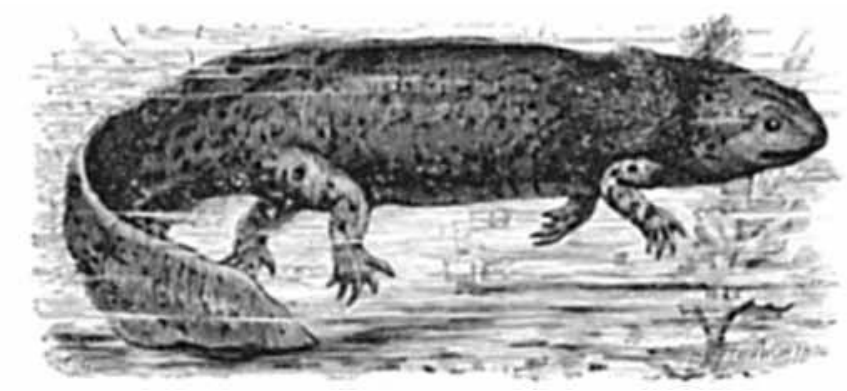

Fic. 2.--1xolotl.

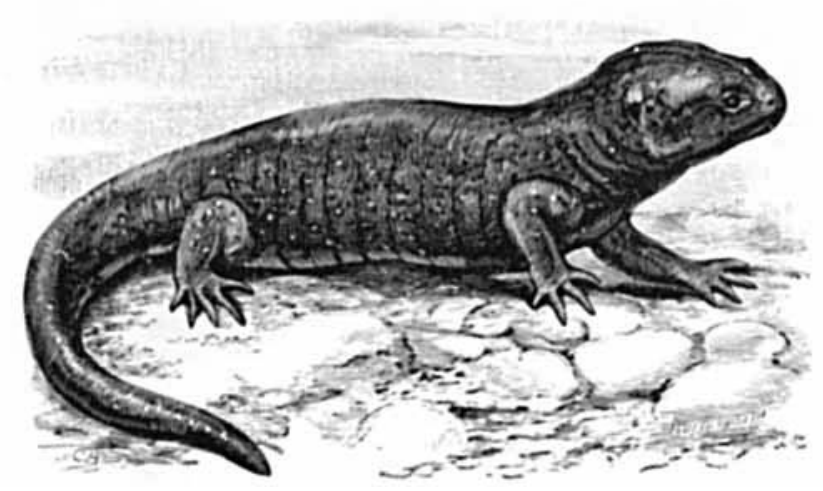

FıG. 3,-Tiger solamander.

in three weeks, as against seven to forty weeks (Madame (hauvin) and six to twelve weeks (E. G. Boulenger) under normal conditions.

Two structures in the body of vertebrate animals have always had for me a peculiar fascination-the notochord and the pituitary body ; each is as constant as the backbone. The discovery of the influence of the pituitary secretion on the growth of bones opened the eves of physiologists, and they slowly realized that the growth and development of animal bodies are governed by a glandular pantheon, and of the divinities in this curious pantheon the pituitary body presides over the growth of the skeleton.

It must strike even a casual observer as strange that two contrasted men such as Patrick Cotter, the Bristol giant, and the fat man, Danicl Lambert, weighing $739 \mathrm{lb}$., whose portrait adorned many tavern signs, were products of disordered glandular action (Fig. 4). 
The discovery that Hunter's giant, Charles Byrne, alias O'Brien, had an enlarged pituitary body, is one of the romances of the museum. After Marie discovered the relationship of the pituitary body to arromegaly, surgeons became interested in studying its effects on the skeleton. Prof. D. J. Cunningham, during a visit to the museum, slipped his finger through the foramen magnum of the unopened skull of the giant, and found the pituitary fossa shallow and expanded : its walls had undoubtedly been levelled

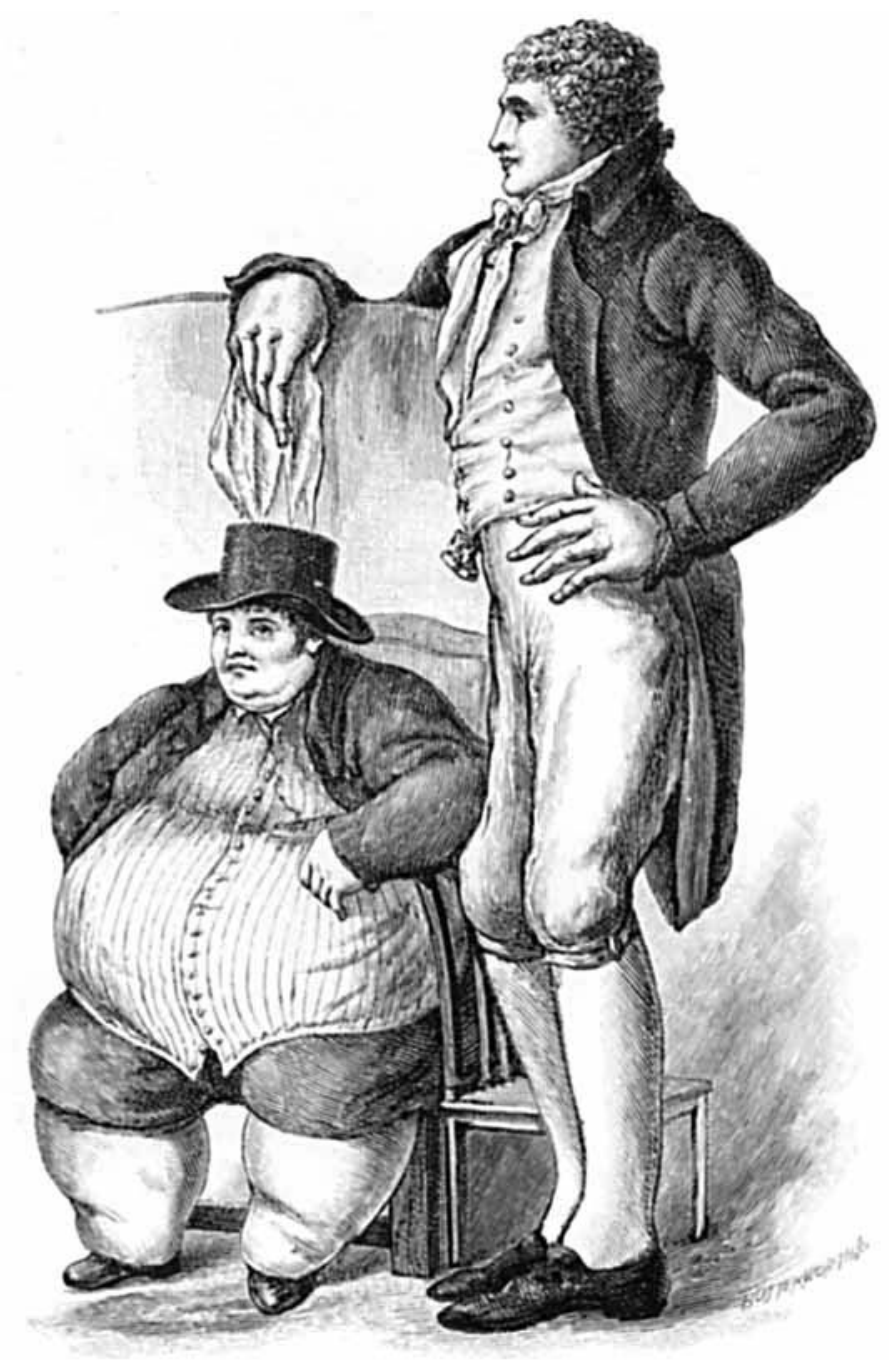

FIG. 4.-Patrick Cotter, the Bristiol giant, 8 ft. 7 in., and Daniel Lambert.

(Kirby's Wonderful Juesum, 18144, vol. ii.)

by an enlarged hypophysis. Keith subsequently cut a movable lid in the cranial vault and made the eroded fossa available for easy inspection. Patrick Cotter was a contemporary of Hunter's giant in London. He had big hands, and a cast of one is preserved in the College Museum. Cotter was caricatured by Rowlandson in 1785, two years after Hunter's giant was dead and skeletonized. Grego, Rowlandson's biographer, describes the caricature as being drawn with skill and originality; it represents the giant as 
graceful though gigantic. In the picture, the giant's right hand is resting on the liead of a military commander. 'Jhe ladies are struck with wonder at such gigantic linıbs, and one is comparing her tiny foot with the large and well-proportioned member of the giant (Fig. 5). The sketch contains other whimsicalities, and hangs in the conservator's oflice.

The most striking feature of giants, apart from their height, is the enormous size of their hands. 'This is shown in the drawing and in Rowlandson's caricature. 'These drawings were made nearly a century before acromegaly was detected or suspected.

Goliath of Gath, whose height was six cubits and a span (9 ft. 9 in.), had big hands, for the staff of his spear was like a weaver's beam.

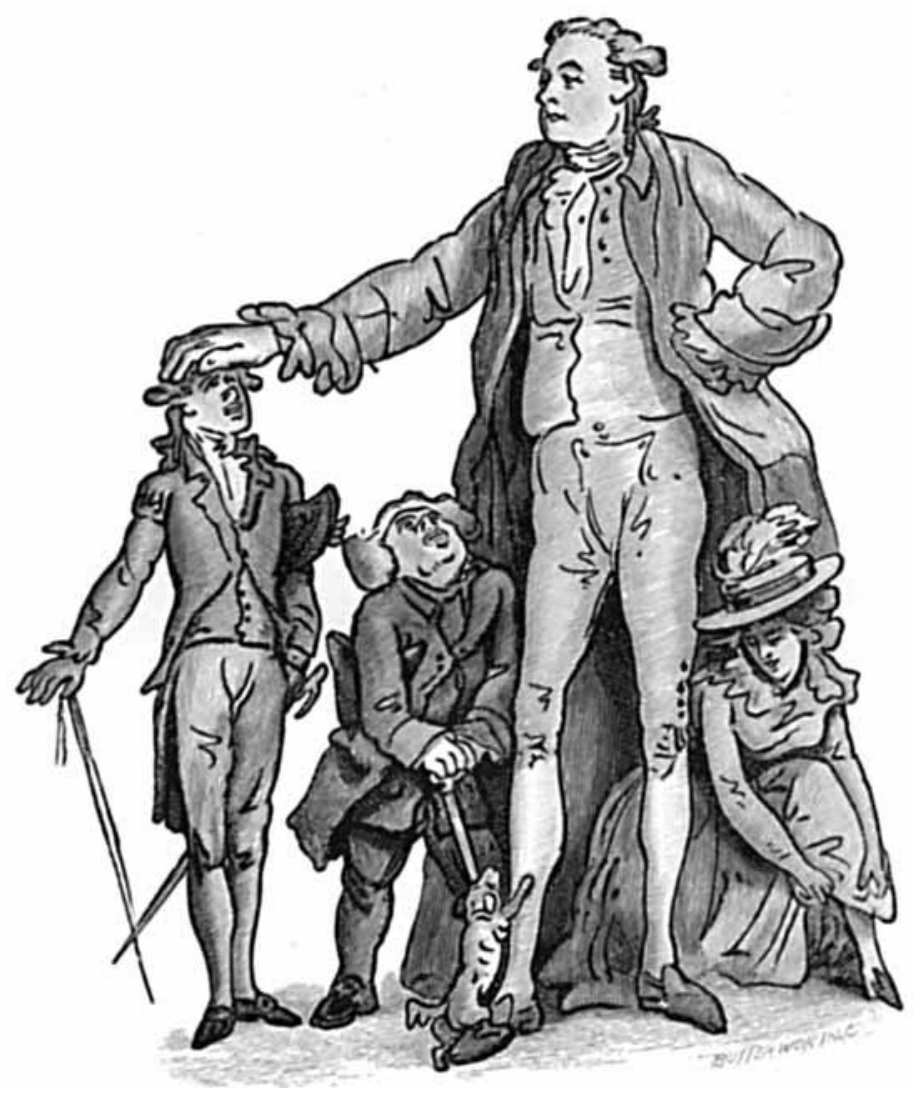

Fig. 5.-The astonkiking Irish Giant, 1785. (Rotclandson.)

I saw the hand of an acromegalic musician that could span 16 inches. 'This man played the double bass, and his wide span gave him excellent control over the strings.

It is strange that overgrowth of the most cunningly concealed glandular body in man is responsible for making its owner the most conspicuous person in an assernbly. In spite of the apparent inaccessibility of the hypophysis in its neat little cave in the base of the skull, the radiologist can ascertain its dimensions during life with the same certainty with which he detects stones in the kidney.

Avian Clubs.--Some remarkable effects of glandular activity on the character and dress of birds may be studied in sparrows. In winter these birds, cocks and hens, live in flocks, and their twittering in tle trees at sunset is a familiar feature in the dull 
season. These societies may be called avian clubs, and they are sociable meetings, for in winter the testicles of the cocks are about the size of the pips of pippins (Fig. 6). In March, as the days lengthen and there is more sunshine, the testicles enlarge, and in May they are as big as sparrows' eggs. Apart from the spccial reproductive functions associated with the testicular increase, there are two features of importance : the colour of the feathers is more vivid, and the bird becomes pugnacious and combative. The sparrow is such a common bird that most of us take as little notice of it as of the Iitany, but the nut-brown plumage of the cock sparrow in April is exquisite, when with trailing half-spread wings he deploys before the coy hen, and is so absorbed in the pursuit as to forget the presence of man.

Jackson's whydah bird presents a good example of resplendent nuptial plumage. This bird is closely allied to the sparrow, and in the quiet season it is difficult to distinguish by plumage the cock from the hen. On the approach of the pairing season the cock undergoes an extraordinary change. All the fcathers except the primaries and secondarics become black ( $F$ igs. 7,8 ). The tail feathers lengthen and assume a sickle shape.
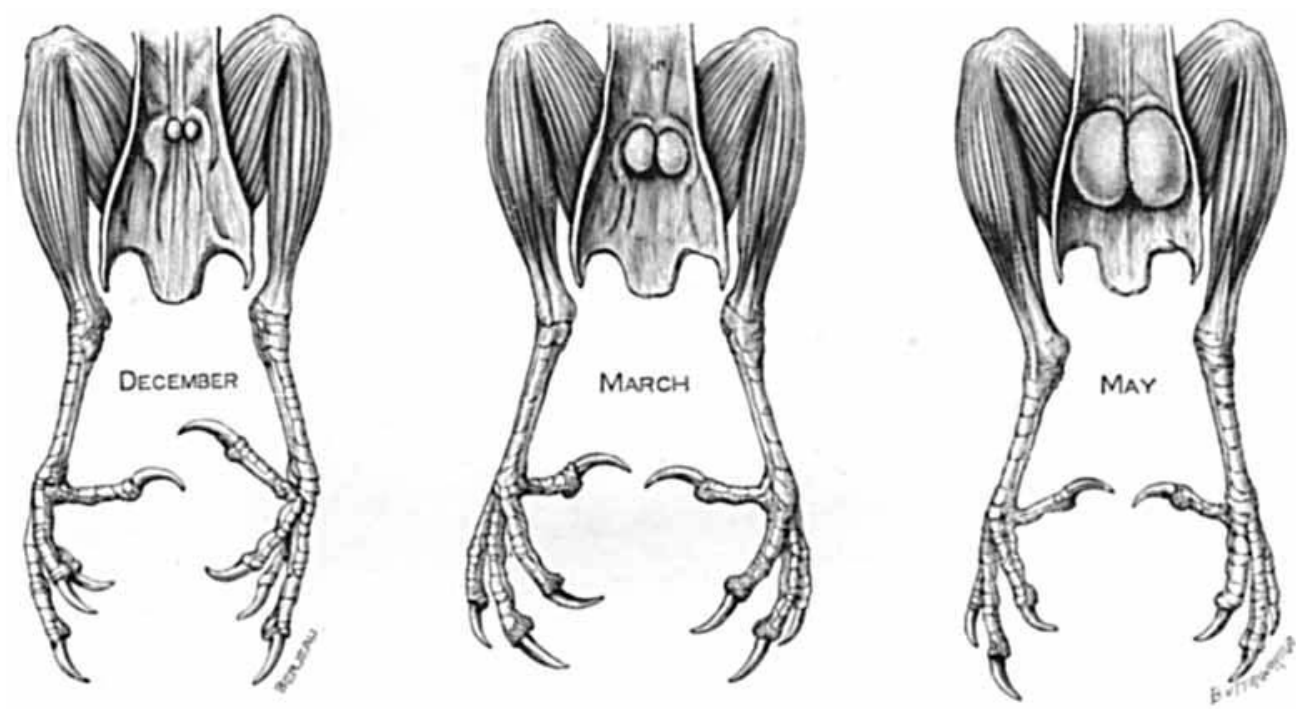

FIG. 6.- Seasonal changes in the sparrow's testicles.

In flight, the tail spreads out like a parachute, and the bird seems to float rather than fly. During courtship the cock indulges in extraordinary antics, in which wings and tail play a conspicuous part. At the end of the breeding season the cock moults, and cocks and hens live in communities, consisting of thousands, among the reeds.

It is remarkable that this finch in a few days produces a large amount of feathers, large in comparison with its bulk, and as black as ink. The source of the pigment is unknown. I often think that if its source were known, much of our ignorance in regard to melanoma would be dissipated.

It is a simple question to ask, Why does the cock have such fine plumage for the ceremonies of courtship, whilst the hen is covered with sonibre feathers? It is more puzzling to explain why a hen, when she grows old and ceases to lay eggs, occasionally becomes cock-feathered.

In 1917 the College of Surgeons acquired the drawing of a duck (Fig. 9) feathered like a drake, even to the curly feathers on the tail. Under the drawing, in John Hunter's handwriting, is the statement that the bird made a noise sometimes like a duck and sometimes like a drake. The sexual difference in the voice of the duck and the drake 
is well known, and is associated with a modification of the syrinx. In the drake there is an osseous bulb (Fig. 10) or labyrinth connected with the trachea and syrinx. The quack of the duck is loud and sonorous; of the drake, inward, harsh, and feeble. On a dark night, when these birds assemble by hundreds in marshes and shallow cstuaries, they quack apparently for the sake of keeping company (Gilbert White). It is easy to distinguish the voice of the duck from that of the drake. It would be useful to ascertain if drake-feathered ducks also acquirc a labyrinth to their syrinx.

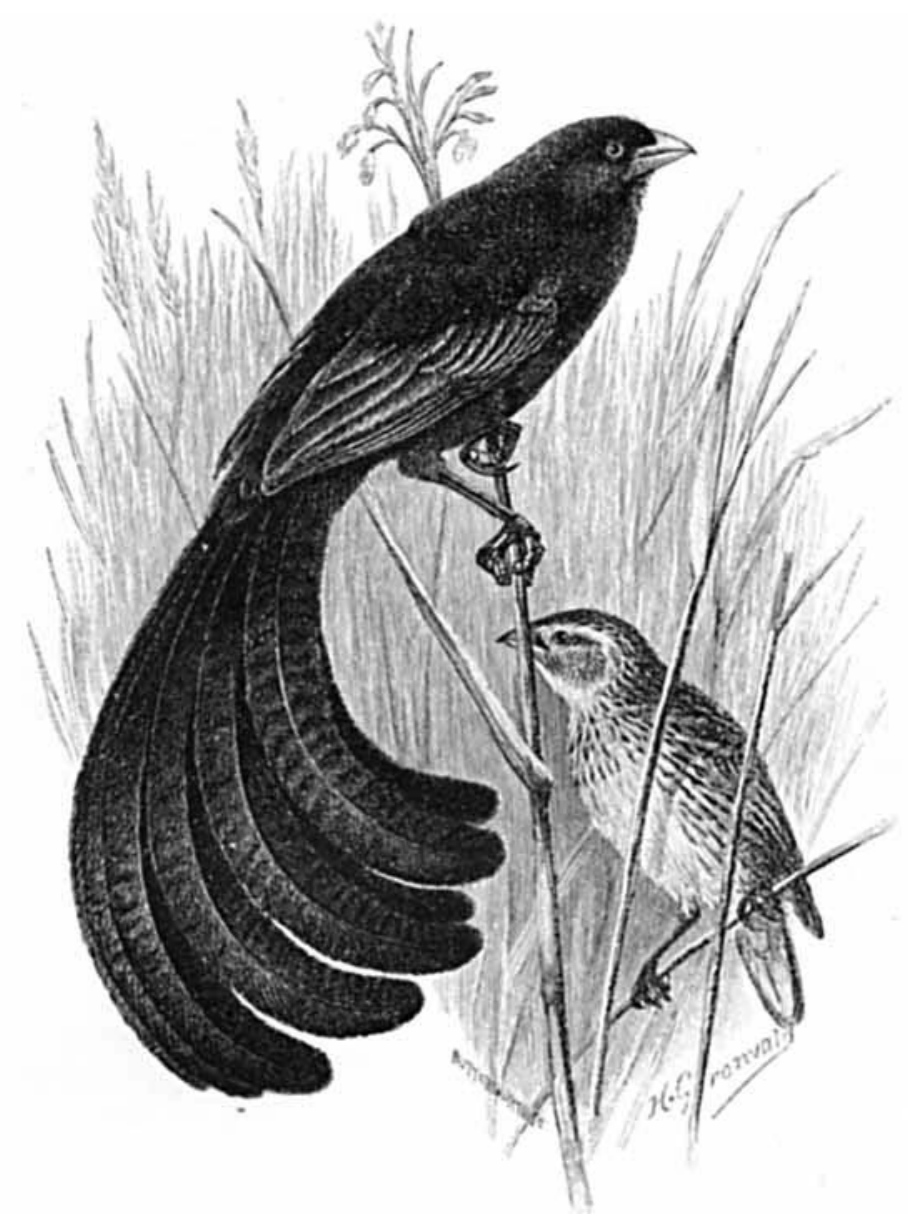

Frg. 7.-Jackson's whydah birds, cock and hen.

Testicles and Feathers.-The relationship of testicles and featheis has practical importance for the ostrich farmer. Stanley Elley, a veterinary surgeon, practised the caponizing of ostriches in South Africa to eheck the breeding of inferior birds. The operation also enhances the value of feathers, tames vicious birds, and produces good parents. Sir Arnold Theiler informed me that during the war caponization practically ceased because of the slump in ostrich feathers, and the number of birds has enormously decreased.

In a bachelor ostrich the testicles weigh about an ounce, but in an old cock a pair weigh about $2 \mathrm{lb}$. The operation is not difficult, the risks are small, and the bird seems immune to peritonitis. In the hen the ovary is removed with good results. In cocks 
the effects of castration on the feathers is due to the subsequent docility of this combative bird. Fighting spoils feathers. In the hen the value of the feathers is enhanced because the bird becomes cock-feathered and the feathers tend to become black.

A critic may ask, What have testicles to do with feather production when a hen without any trace of ovarian or testicular tissue becomes cock-feathered ? The evidence suggests that the endocrine glands are closely correlated in sex manifestations. Morgagni is credited with the observation that there is relationship between the development of the cerebral cortex and the cortex of the adrenal, but it is a modern discovery that

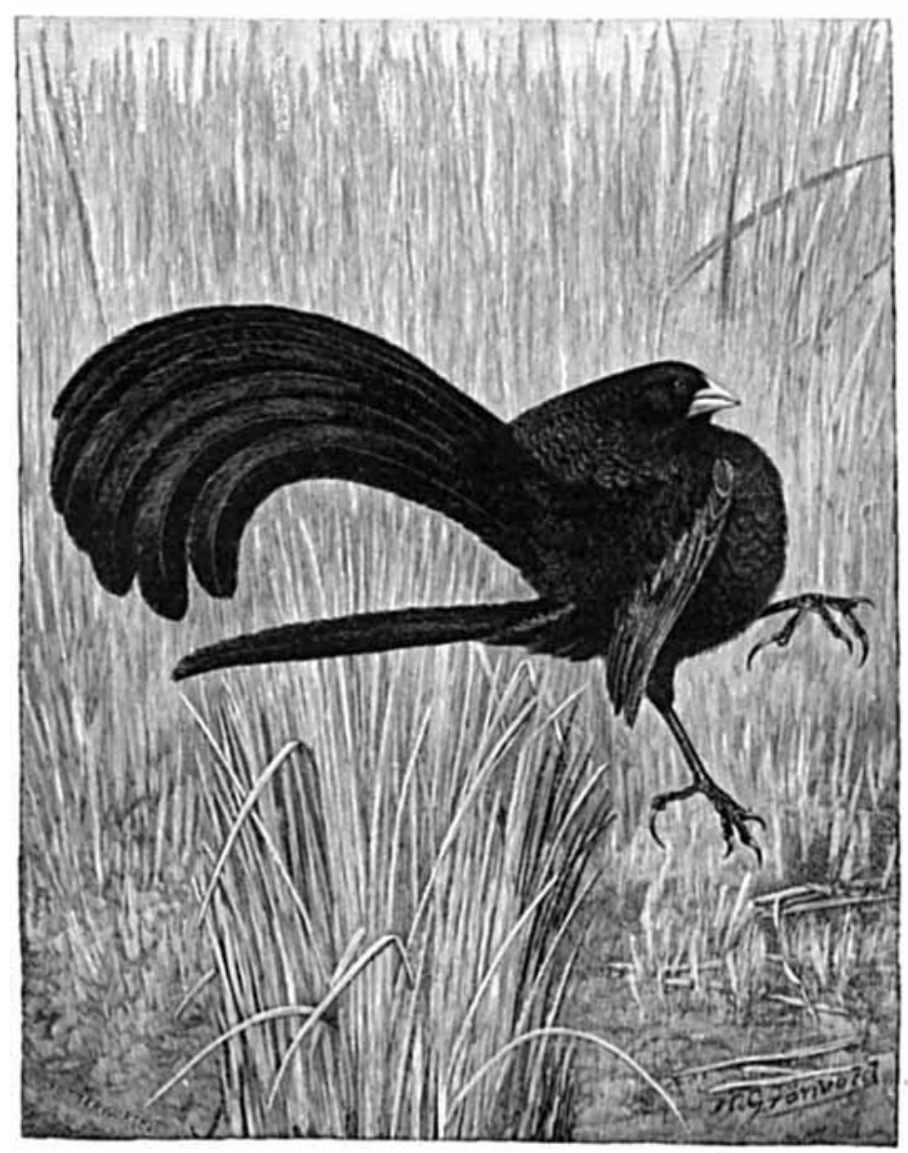

FIf. 8.-Tackson's whydah bird daneing in its playing-rgroumd,

the adrenals are associated with the activity of the sexual organs. Mott regards the adrenal cortex as a storage of lipoid: in the foetus it builds up the myelin of the developing nervous system, but in adults, as occasion arises, this lipoid can pass into the blood and keep constant the supply for the reproductive organs, where it serves as raw material for formative nuclear activity, an action essential for the production of spermatozoa.

The hormone secreted by the genital glands must be very potent, for the engrossment of the sexual act is such that amplectant frogs are often transfixed by inquisitive boys with sharp sticks, and Phinehas, Aaron's zealous grandson, treated a man of' Israel and a 
Midianitish woman in the same fashion with a javelin (Num. xxv. 7). Shackleton has collected photographic evidence that love is as ardent among birds and beasts

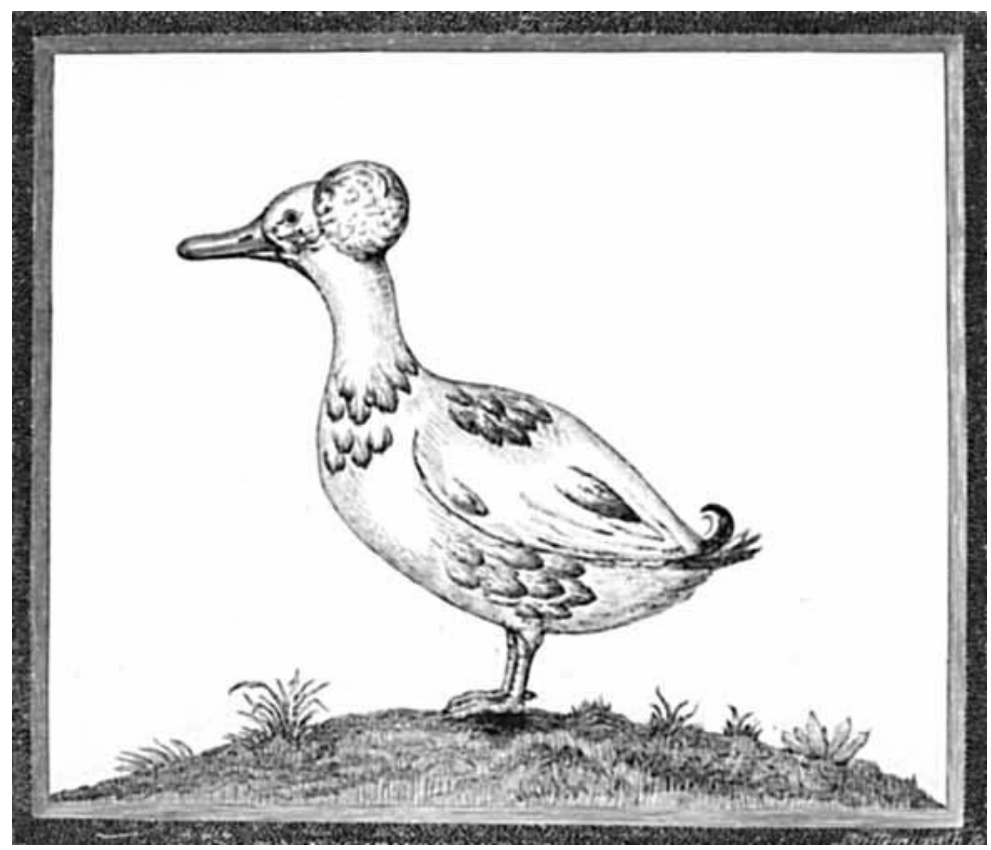

Fit, 9.-Duck iı drake plumage.

during the cold summer of the Antarctic as in the heat of the Torrid Zone.

The enterprising spirit of South African veterinary surgeons is matched by their colleagues in Canada and the Iinited States, where they make skunks as respectable as castrated cats, and much more profitable. Young skunks are obtained in May, as soon as their eyes are open, for then they are easily weaned and will eat bread and milk. The anal glands-scent-sacs they are euphemistically called in America-can be easily, safely, and almost painlessly excised in the young skunk. This operation-called 'disarming the skunk'- requires for its performance a scalpel, forccps, clamping forceps, hook, probe, and a pair of goggles. The clamping-forceps prevent the escape of the stinking fluid, and the use of goggles saves the operator's eyes in case of such an accident.

A disarmed skunk makes a good pet, and may be carried about like a kitten : it eats dead fowls, mice, fruit, vegetables, grubs, and beetles.

Skunk fur is admired by women, and the fur can be improved by cross-breeding.

Among other advantages claimed for a disarmed animal, is this : a tame skunk placed in the window of a store for advertising purposes will draw a big crowd.

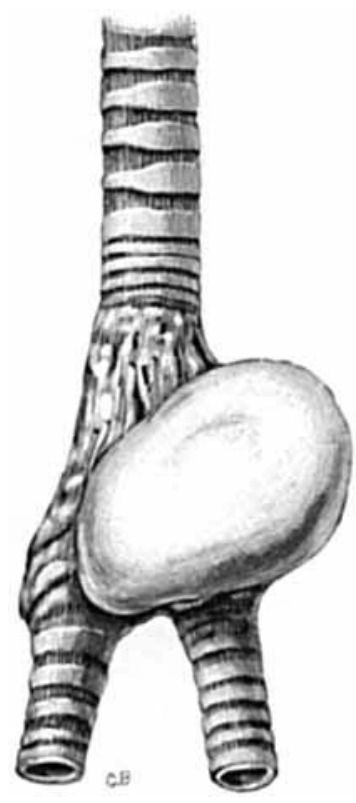

FIG. 10.-The $\operatorname{syrinx}$ of a drake (Anas boscrs). 
EMBRYOLOGY.

Next to speculations on the beginning of the world, nothing absorbs attention more than the origin of life, and the production of animals out of themselves always excites wonder and curiosity. The relationship of embryology to surgery has always had for me an irresistible attraction. I vainly imagined that embryology would help to solve the problem of the origin and growth of tumours, and a large part of my leisure for many years was devoted to this question. Of all tumours, dermoids attracted me, especially those which arise in the ovary. In relation to these singular tumours, which fifty years ago were regarded as curiosities, much has been learned, and the chief light on their origin has come from experimental embryology.

Patient section-cutting, and observation in the laboratory, proved that the tissues of the embryonic rudiment in an ovarian dermoid contained imperfcetly developed tissues, and organs of an embryo--skin, hair, glands, teeth, cartilage, bone, trachea, thyroid gland,

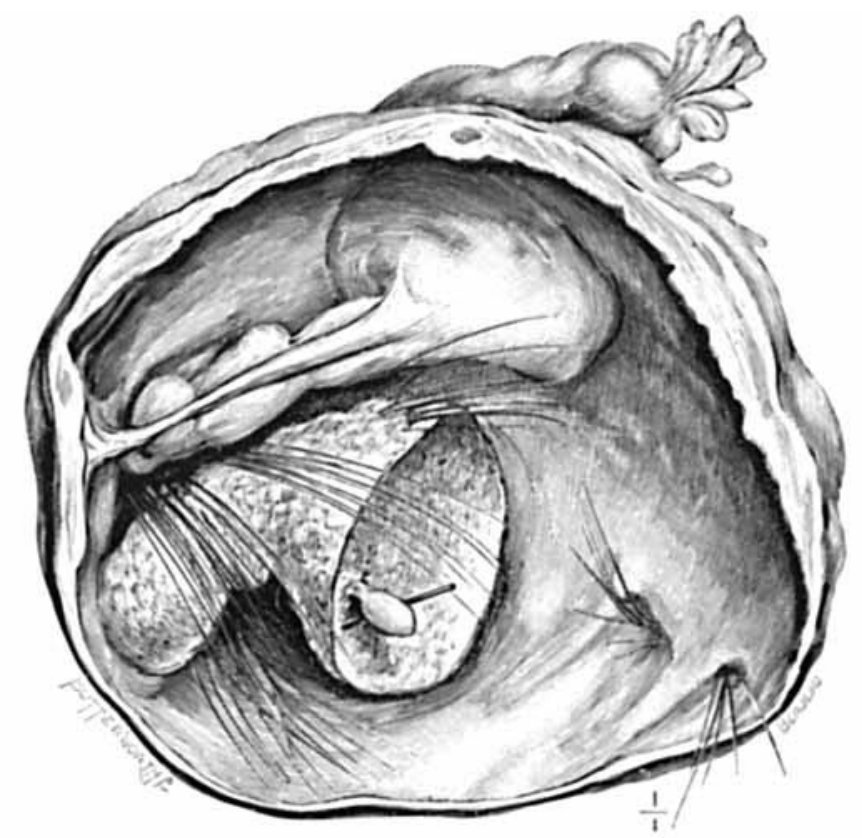

Fir. 11.-Ovarian dermoid. The small oval strueture in the embryonic rudiment is inrested with stout fibrous tissue, atul contains nerve cells ind medultuted tbres. (St. Thomas's Hospital $1 /$ useum.)

brain, eye, spinal cord, and (rarely) intestine, but so far no reprorluctive glands. In an embryonic rudiment in an ovarian dermoid removed from a woman, age 30, Shattock isolated a small oval structure invested with a capsule of stout fibrous tissue which, as told micruscopically, contains nerve cells and some medullated fibres (Fig. 11). It gradually dawned on pathologists that these conglomerations of foetal tissues could only be produced by the activity of an ovum ; but observational embryology led men to believe that an ovum could only be stimulated by a spermatozoon of its own species. Since the discovery that mechanical stimulation is sufficient to start segmentation in an ovum, it has become a commonplace experiment in biological laboratories to irritate frogs' eggs with delicate stylets and produce what are now known as 'fatherless frogs'. 'These successful experiments indicate that ovarian dermoids might not inaptly be called 'fatherless embryos'.

'These experiments can only be carried out on large eggs like those of the frog and its 
kind. The method is not available for the production of race-horses, nor for heirs to ancient titles or great estates, when the sire is impotent : nor is there any reason to belicve that it will relieve human beings of what St. Paul politely styles evil concupiscence (Colos. iii).

\section{LAMPS AND SPECIALISM.}

Before the invention of the incandescent lamp, the chicf specialities rested on instruments that reflected sunlight, lamplight, or gaslight. By such simple means advances were elfected in laryngology, ophthalmology, and gynæcology. The incandescent lamp enabled ingenious instruments to be constructed for illuminating internal cavities. To this class belong the cystoscope, bronchoscope, and sigmoidoscope. Each instrument requires skill in employment and experience in interpreting things seen. This accounts for much dismemberment in clinical surgery.

Radiology has transformed the methods of diagnosis in respect of intrathoracie discase. Good skiagrams of the chest will reveal calcified lymph-nodes, tumours of the mediastinum, and aneurysms of the big vessels. With the help of an opaque meal an intrathoracie stomach has been identified, and an osophageal diverticulum can be localized and its size and suitability for removal duly estimated.

In the case of a foreign body in the chest, the utility of the $x$ rays has long been demonstrated, and the detection of a sovereign or a bicycle-a toy bicycle-in the gullet excites curiosity, but it is a dramatic spectacle to watch a shrapnel ball in a cardiac ventricle, rapidly moving in its orbit, and recalling, in its activity, Phobos, the little satellite of Mars.

The chest is now an established field for surgical enterprise. There are indications that $x$-ray lamps and screens will be as available in wards and consulting-rooms as incandescent lamps are to-day.

The art of surgery is now so wide that no man can expect to be expert in all branches. Specialization is a necessity of modern surgery ; the Association will help to concentrate the results and keep surgeons abreast of the progress made in the great liospitals of the kingdom. Apart from the regular discussions, personal conversations will be even more useful, and promote good fellowship among surgeons.

Before all things let us remember that fellow-craftsmen should not be competitors, but comrades of the same honoured craft or guild. 